RESIDENT

\& FELLOW

SECTION

Section Editor

Mitchell S.V. Elkind,

MD, MS

H.-Y. Choi, MD

M.G. Lee, MD

B.S. Ye, MD

H.J. Cho, MD

D.J. Kim, MD

J.H. Heo, MD, PhD

VIDEO

\title{
Teaching NeuroImages
}

Bilateral cerebellar infarction in

dominant superior and anterior inferior cerebellar arteries

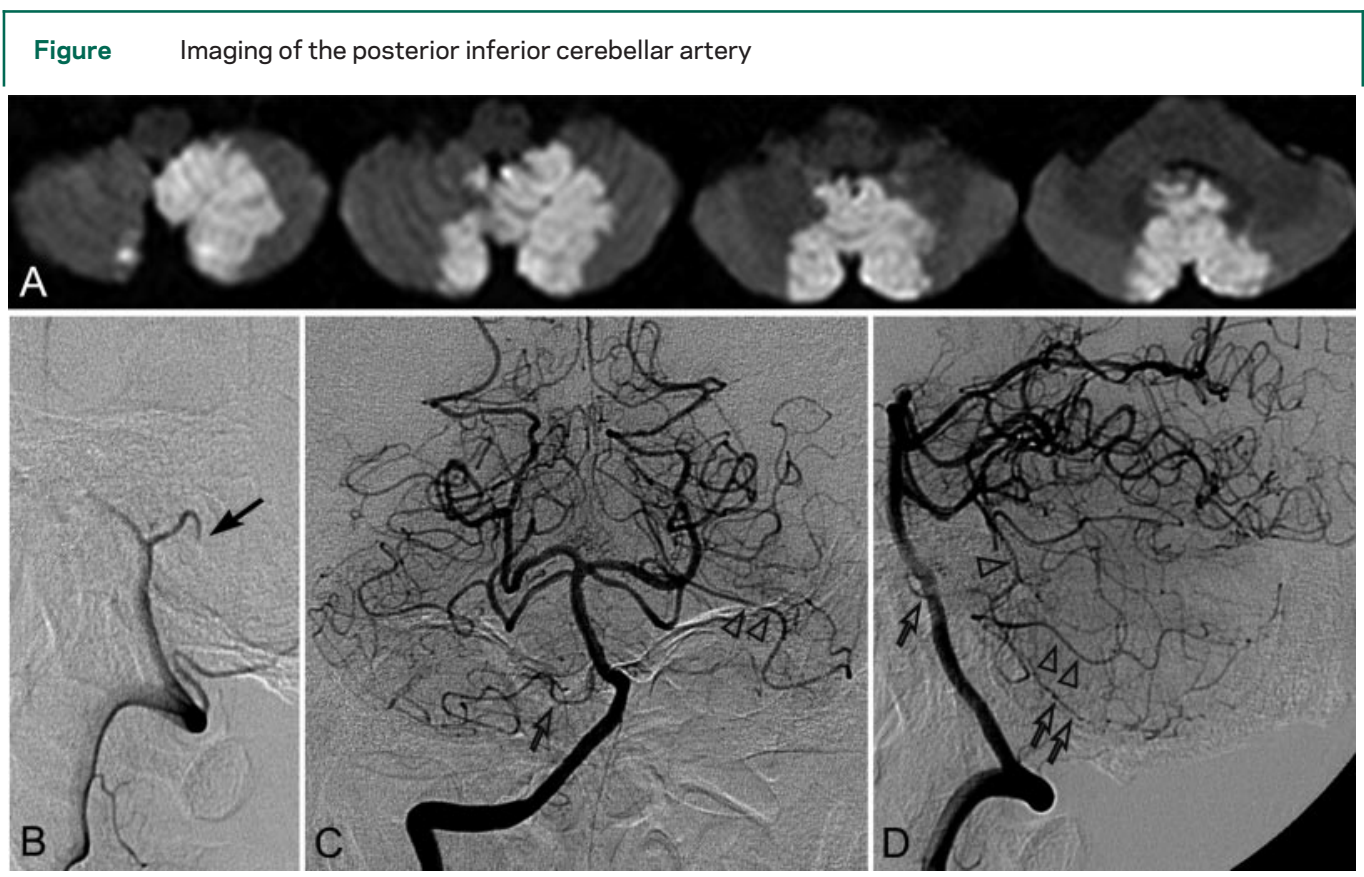

(A) Diffusion-weighted MRI demonstrates a bilateral infarction in the medial cerebellum. (B through D) Angiography shows an occlusion of the left posterior inferior cerebellar artery (PICA) (filled arrow), absence of the right PICA origin, and the presence of the dominant anterior inferior cerebellar artery (open arrows) and the superior cerebellar artery (arrowheads).

A 64-year-old man with diabetes mellitus presented with abrupt vertigo. MRI revealed an infarction in the bilateral cerebellum in the territory of the medial posterior inferior cerebellar artery (PICA) (figure, A), which is rare. ${ }^{1}$ Angiographic findings demonstrated that the infarction limited to the medial cerebellum was caused by the presence of rare variants of cerebellar arteries. They include the dominant anterior inferior cerebellar artery and the dominant superior cerebellar artery, ${ }^{2}$ which take over the territories that are usually perfused by the lateral PICAs (figure, B through D), along with the single medial PICA that supplies the medial areas of the bilateral cerebellum.

\section{REFERENCES}

1. Han SW, Cho GC, Baik JS, Park JH, Kim JY, Heo JH. Bilateral cerebellar infarction caused by dominant medial posterior inferior cerebellar artery. Neurology 2006;66:1125-1126.

2. Newton TH, Potts DG. Radiology of the skull and brain. St. Louis: Mosby, 1974.

From the Departments of Neurology (H.-Y.C., M.G.L., B.S.Y., H.J.C., J.H.H.) and Diagnostic Radiology (D.J.K.), Yonsei University College of Medicine, Seoul, Korea.

Received January 19, 2007. Accepted in final form March 6, 2007.

Address correspondence and reprint requests to Dr. J.H. Heo, Department of Neurology, Yonsei University College of Medicine, 134 Shinchon-dong, Seodaemoon-gu, 120-752, Seoul, Korea

jhheo@yumc.yonsei.ac.kr

Supported by a grant from the Korea Health 21 Research and Development Project, Ministry of Health and Welfare, Republic of Korea (A060272).

Disclosure: The authors report no conflicts of interest. 


\section{Neurology}

\section{Teaching NeuroImages Bilateral cerebellar infarction in dominant superior and anterior inferior cerebellar arteries \\ H. -Y. Choi, M. G. Lee, B. S. Ye, et al. \\ Neurology 2007;69;E4 \\ DOI 10.1212/01.wnl.0000267326.20595.d2}

This information is current as of August 13, 2007

Updated Information \& Services

References

Permissions \& Licensing

Reprints including high resolution figures, can be found at: http://n.neurology.org/content/69/7/E4.full

This article cites 1 articles, 1 of which you can access for free at: http://n.neurology.org/content/69/7/E4.full\#ref-list-1

Information about reproducing this article in parts (figures,tables) or in its entirety can be found online at:

http://www.neurology.org/about/about_the_journal\#permissions

Information about ordering reprints can be found online: http://n.neurology.org/subscribers/advertise

Neurology ${ }^{\circledR}$ is the official journal of the American Academy of Neurology. Published continuously since 1951, it is now a weekly with 48 issues per year. Copyright. All rights reserved. Print ISSN: 0028-3878. Online ISSN: 1526-632X.

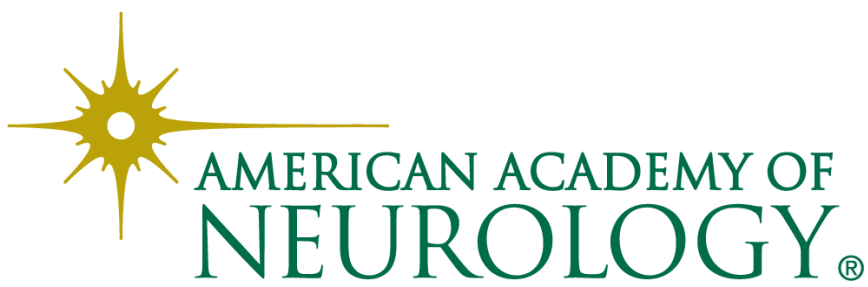

